\title{
Modifikasi serat limbah kubis menjadi nanokristalin selulosa melalui metode hidrolisis asam
}

\section{(Waste cabbage fibers modification into nano-crystalline cellulose via acid hydrolysis method)}

\author{
Andi Arjuna, Selva Natsir, Andi Amelia Khumaerah, Risfah Yulianty
}

Fakultas Farmasi, Universitas Hasanuddin, Makassar, Indonesia, 90245

\section{Article Info:}

Received: 10 September 2018

in revised form: 20 September 2018

Accepted: 01 October 2018

Available Online: 01 October 2018

\section{Keywords:}

Acid hydrolysis

Crystalinity index

Nanocrystalline cellulose

Waste cabbage

\section{Corresponding Author:}

Andi Arjuna

Fakultas Farmasi

Universitas Hasanuddin

Makassar, 90245

Indonesia

Mobile: 082345748488

Email: andiarjuna@unhas.ac.id

\begin{abstract}
As one of vegetable plants in South Sulawesi, cabbage (Brassica oleracea L.) crops has generated cellulose fibers biomass which is potentially modified into nano-crystalline cellulose, a valuable material in the pharmaceutical formula. Therefore, this study aims to manipulate the natural cellulose fibers of cabbage biomass through acid hydrolysis method within product preliminary evaluation through FT-IR and XRD. The fibers were modified through the bleaching process produce micro crystalline cellulose, which was then hydrolyzed with $65 \%$ sulfuric acid to obtain nanocrystalline cellulose. The products have yellow pale to brown colour, with a yield of $10.06 \%$ and $31.16 \%$ respectively. Based on FT-IR spectra, both products inherit cellulose characteristics, C-O (1232.16 cm-1); C = O (1743.65 cm-1); -OH (1625.99 cm-1); C-H (2920.23 cm-1); O-H (3414 cm-1). The increasing trend of crystallinity index during the process was also observed in XRD diffractogram. It is identifiable from $7.41 \%$ for natural fiber, $69.68 \%$ for crystalline microcrystalline, and $78.01 \%$ for nano crystalline cellulose. Through Match ${ }^{\circledR}$, the estimated crystalline product size reaches $58.91 \mathrm{~nm}$.
\end{abstract}




\begin{abstract}
ABSTRAK
Kubis merupakan salah satu tanaman sayuran yang setiap panennya menyisakan biomassa serat selulosa yang berpotensi dimodifikasi menjadi nanokristalin selulosa, bahan tambahan pada formulasi sediaan farmasetika. Oleh karena itu, penelitian ini bertujuan untuk memanipulasi serat alami biomassa selulosa kubis melalui metode hidrolisis asam dengan evaluasi pendahuluan kualitas produk melalui FT-IR dan XRD. Serat alami dimodifikasi melalui proses bleaching menghasilkan mikro kristaline selulosa, yang dihidrolisis dengan asam sulfat 65\% untuk mendapatkan nanokristalin selulosa. Produk yang diperoleh berwarna kuning lemah dengan rendamen masing-masing $10.06 \%$ dan $31.16 \%$. Berdasarkan spektra FT-IR, kedua produk tetap menunjukkan karakteristik selulosa dengan bilangan gelombang C-O $\left(1232,16 \mathrm{~cm}^{-1}\right) ; \mathrm{C}=\mathrm{O}\left(1743,65 \mathrm{~cm}^{-1}\right)$; $-\mathrm{OH}\left(1625,99 \mathrm{~cm}^{-1}\right)$; C-H $\left(2920,23 \mathrm{~cm}^{-1}\right)$; O-H $\left(3414 \mathrm{~cm}^{-1}\right)$. Trend peningkatan indeks kristalinitas juga ditemui pada difraktogram XRD, dapat diidentifikasi dari 7.41\% untuk serat alami, 69.68\% pada mikro kristalin, dan 78.01\% pada nano kristalin selulosa. Melalui Match ${ }^{\circledR}$, estimasi ukuran produk kristalin mencapai $58.91 \mathrm{~nm}$.
\end{abstract}

Kata Kunci : hidrolisis asam, indeks kristalitas, nanokristalin selulosa, limbah kubis

\section{PENDAHULUAN}

Kubis merupakan salah satu tanaman sayuran yang popular dibudidayakan diperkebunan kabupaten Enrekang, Sulawesi Selatan. Biasanya setelah dipanen, bagian luar tanaman ini hanya menjadi limbah perkebunan yang kurang dimanfaatkan. Padahal, walaupun hanya mengandung sekitar $18.80 \%$ serat, kubis yang mengandung selulosa alami berpotensi besar diolah menjadi bahan bernilai tinggi seperti mikro dan nano kristalin selulosa (Sumpena, Baloch et al, 2015). Kandungan serat selulosa yang dimilikinya menawarkan keuntungan seperti lebih ramah lingkungan, biodegradable, biocompatible, murah, dan tidak membuthkan energy yang banyak dalam penyiapannya (Rosli et al, 2013).

Selulosa, dan beberapa bentuk kristalnya yang telah banyak diketahui manfaatnya seperti mikrokristalin selulosa maupun nanokristal selulosa merupakan polimer yang umumnya digunakan dalam semua sediaan farmasi. Bahan-bahan tersebut bermanfaat sebagai bahan pengisi (diluent), bahan pengikat (binder), bahan penghancur pada sediaan farmasetika padat, seperti tablet dan kapsul. Selain itu, kristalin selulosa juga banyak digunakan sebagai peningkat viskositas pada sediaan farmasetika cair dan semi padat (Rowe et al, 2009, Peng et al, 2011)

Nanoselulosa merupakan salah satu nanomaterial terbaru dengan pengaplikasiannya yang luas seperti sebagai bahan tambahan atau excipient dengan ukuran partikel dalam skala nanometer yang dapat diproduksi dari bahan kapas, tanaman perdu serta bahan buangan atau limbah seperti ampas tebu dan sekam padi serta dari bakteri. Umumnya nanoselulosa memiliki ukuran $100 \mathrm{~nm}$ dengan panjang berkisar antara $100 \mathrm{~nm}$ hingga mikrometer. Nanoselulosa memiliki kelebihan dari segi kekentalan yang tinggi serta modulus Young atau ketahanan elastisitas mencapai 138 GPa yang lebih baik dibandingkan dengan bahan tambahan yang lainnya (Yue, 2011; Bharimalla et al, 2015).

Terdapat berbagai metode untuk mengubah kristal selulosa menjadi nanokristal selulosa, melalui (a) metode mekanik yang menggunakan tekanan tinggi (High Pressure Homogenizer) dan ultrasonikasi, (b) biologi, menggunakan digesti enzimatik dan (c) kimia, menggunakan metode organolosv, pelarut basa (alkali), metode oksidasi menggunakan cairan ionik serta metode asam menggunakan hidrolisis asam (Effendi et al, 2015).

Nanokristalin selulosa yang dihasilkan dari hidrolisis asam memiliki morfologi yang berbeda dari serat selulosa mentahnya. Nanokristalin selulosa memiliki struktur kristal seperti batang atau balok yang rapat dengan diameter pada kisaran 10-20 nm dengan panjang ratusan nanometer, kristal yang terbentuk memiliki ukuran dengan kisaran mikrometer. Selain itu, kristal yang dihasilkan dengan sumber serat kayu dan kapas memiliki ukuran pada kisaran nanometer (Na Ma et al, 2015).

Limbah perkebunan serat alami selulosa sangat berpotensi dimanfaatkan menjuadi nanokristalin selulosa melalui metode yang sederhana seperti hidrolisis asam menggunakan asam sulfat 65\%. Produksi nanokristal selulosa dengan metode asam tersebut dilakukan dengan tahapan penghilangan 
hemiselulosa dan delignifikasi, bleaching serta hidrolisis asam. Pemisahan cairan asam dengan nanokristal selulosa dilakukan dengan sentrifugasi menggunakan air suling hingga $\mathrm{pH}$ netral konstan (Zain et al, 2014). Selulosa diubah menjadi nanokristalin selulosa dengan bentuk kristal datar dan panjang dengan ukuran nanometer, dihasilkan dari hidrolisis asam sulfat pada bagian amorf sehingga terbentuk nanokristal selulosa (Effendi et al, 2015).

Penelitian-penelitian mengenai transformasi serat menjadi kristalin selulosa telah banyak dilakukan, namun pemanfaatan limbah perkebunan seperti kubis yang khusus ditemui di Enrekang, Sulawesi Selatan masih sangat trerbatas. Oleh karena itu, dalam penelitian ini telah dilakukan upaya modifikasi serat kubis menjadi nanokristalin selulosa melalui metode sederhana hidrolisis dengan asam.

\section{METODE PENELITIAN}

\section{Alat dan Bahan}

Alat-alat yang digunakan adalah reflux $\left(\operatorname{Duran}^{\circledR}\right), X$ ray diffractometer-7000 $\left(\right.$ Shimadzu $\left.^{\circledR}\right)$, Frezee-drying $\left(\right.$ Coolsafe $^{\circledR}$ ), Sentrifus (Hettich Zentrifugen ${ }^{\circledR}$ ), Fourier Transform Infrared (Shimadzu $\left.{ }^{\circledR}\right)$.

Bahan yang digunakan adalah limbah kubis (Brassica oleracea L.) dari perkebunan kubis di Kabupaten Enrekang, Mikrokristalin selulosa dari Laboratorium Farmasetika (Unhas), air suling, buffer asetat $\left(\right.$ Merck $\left.^{\circledR}\right)$, asam sulfat $65 \% \quad\left(\right.$ Merck $\left.^{\circledR}\right)$, natrium hidroksida $\left(\right.$ Merck $\left.^{\circledR}\right)$, natrium hipoklorit $\left(\right.$ Merck $\left.^{\circledR}\right)$, iodium $\left(\right.$ Merck $\left.^{\circledR}\right)$, seng klorida $\left(\right.$ Merck $\left.^{\circledR}\right)$ dari laboratorium Kimia Analisis Farmasi (Unhas).

\section{Metode}

\section{Penyiapan sampel limbah kubis}

Sampel limbah kubis (Brassica oleracea L.) yang didapatkan di perkebunan kubis Kabupaten Enrekang, Sulawesi Selatan, dipilih dan dibersihkan dengan air, kemudian dikeringkan dengan oven pada suhu $50^{\circ} \mathrm{C}$ selama 48 jam. Hasil yang telah dikeringkan kemudian diserbukkan untuk digunakan pada proses selanjutnya (Effendi et al, 2015, Zain et al, 2014) ).

\section{Delignifikasi, penghilangan hemiselulosa, dan bleaching}

Penghilangan lignin dan hemiselulosa dilakukan dengan mengambil serbuk sampel sebanyak 50 gram dicampurkan dengan $400 \mathrm{~mL} \mathrm{NaOH}$ 4\%. Proses dilanjutkan dengan reflux selama 2 jam. Hasil yang diperoleh kemudian difiltrasi dan dibilas dengan air suling, dikeringkan pada suhu $45^{\circ} \mathrm{C}$.

Untuk proses bleaching, sampel kering dicampurkan dengan $300 \mathrm{~mL}$ Natrium hipoklorit 1,7\% + $100 \mathrm{~mL}$ buffer asetat $\mathrm{pH} 3+100 \mathrm{~mL}$ air suling, kemudian direflux selama 30 menit. Hasil proses ini didinginkan dan disaring dengan air suling, dikeringkan pada suhu $50^{\circ} \mathrm{C}$. Sebelum dilanjutkan pada tahapan hidrolisis asam, terlebih dahulu dilakukan uji organoleptis, uji identifikasi dengan uji kelarutan, dan uji dengan larutan iodium (Effendi et al, 2015, Filson et al, 2009).

\section{Hidrolisis asam}

Sebanyak 5\% (b/v) serbuk selulosa hasil bleaching ditambahkan dengan 65\% asam sulfat kemudian dipanaskan selama 45 menit pada suhu $45^{\circ} \mathrm{C}$. Proses ini dilanjutkan dengan pemisahan asam sulfat dengan sentrifus pada kecepatan 3000 rpm selama 5 menit. Untuk menghilangkan asam sulfat, proses ini dilakukan hingga didapatkan $\mathrm{pH}$ netral yang konstan. Hasil yang diperoleh kemudian di beku keringkan sebagai serbuk nanokristallin selulosa (Effendi et al, 2015, Zain et al, 2014, Filson et al, 2009)

\section{Evaluasi kualitas produk}

\section{Evaluasi organoleptik}

Serbuk selulosa diletakkan pada kaca arloji kemudian diamati dengan melihat parameter: warna dasar, bentuk, serta baunya (Zulharmita et al, 2012).

\section{Identifikasi selulosa}

1. Sampel sebanyak $50 \mathrm{mg}$ ditambahkan $540 \mathrm{ml}$ air suling dan dipanaskan selama 15 menit kemudian disaring. Filtrat ditambahkan $0,1 \mathrm{ml}$ iodium 0,05M dengan hasil tidak terbentuk warna biru (Zulharmita et al, 2012, The Department of Health, 2001).

2. Sampel diambil sebanyak $50 \mathrm{mg}$ kemudian ditempatkan pada kaca arloji kemudian didispersikan dengan larutan seng klorida beriodium sebanyak $10 \mathrm{ml}$. Hasil akan menunjukkan warna biru violet (The Department of Health, 2001).

3. Pengukuran dilakukan dengan spektrofotometer FT-IR untuk mengetahui perubahan intensitas tiap-tiap gugus fungsi pada bilangan gelombang spesifik selulosa sesuai dengan perlakuan yang diberikan. Sampel yang akan dianalisis dicampurkan dengan kalium bromida $(\mathrm{KBr})$ 
kemudian diukur pada panjang gelombang 400$4000 \mathrm{~cm}-1$ (Zain et al, 2014).

\section{Kelarutan}

Pengujian dilakukan mengikuti pengujian mikrokristalin selulosa seperti yang tertera pada British Pharmacopeia 2001 Vol.1. Sampel diambil sebanyak 5 gram dan dikocok dengan $80 \mathrm{ml}$ air suling selama 10 menit. Hasilnya disaring dan diuapkan diatas tangas air pada suhu $100^{\circ}-105^{\circ} \mathrm{C}$ selama 1 jam. Bobot sisa tidak boleh lebih dari 0,25\% (12,5 mg) (Zulharmita et al, 2012; The Department of Health, 2001).

Pengujian kelarutan dalam etanol, larutan asam encer, dan larutan natrium hidroksida masing-masing dengan menggunakan sampel sebanyak $50 \mathrm{mg}$ kemudian ditambahkan larutan sebanyak $50 \mathrm{ml}$ pada erlenmeyer. Hasil akan menunjukkan sampel tidak larut dalam pelarut etanol larutan sama encer dan larutan hidroksida.

\section{Evaluasi kristalinitas}

Pengukuran dengan $X$-ray Diffractometer dengan menggunakan radiasi $\mathrm{Cu}-\mathrm{K} \alpha$ dimana deteksi dilakukan pada $2 \theta=5-40^{\circ}$ pada kecepatan $2^{\circ}$ /menit dan diset pada $40 \mathrm{kV}$ dan 30mA. Sampel ditempatkan pada bagian holder kemudian dianalisis index kristal dengan persen total area dan rasio puncak kristal.

\section{Pengumpulan dan analisis data}

Data yang diperoleh kemudian dianalisis. Khusus untuk indeks kristalinitas, data diolah melalui persamaan Segal (24), berikut

Index Kristal $(\mathrm{CrI} \%)=\left[\left(\mathrm{I}_{002}-\mathrm{I}_{\mathrm{am}}\right) / \mathrm{I}_{002}\right] \times 100$,

Analisis dilakukan untuk estimasi kualitas nanokristalin yang dihasilkan dibandingkan dengan produk selulosa lainnya pada tiap tahapan modifikasi (Effendi et al, 2015, Zain et al, 2014)

\section{HASIL DAN PEMBAHASAN}

Modifikasi serat alami seperti selulosa limbah kubis dapat ditempuh dengan berbagai metode utamanya melalui hidrolisis asam yang sederhana. Pada metode ini terdapat beberapa tahapan utama yang mencakup tahapan penghilangan lignin dan hemiselulosa, bleaching atau proses pemutihan yang dapat menghasilkan produk mikrokristalin selulosa, serta hidrolisis asam dengan menggunakan asam sulfat $\left(\mathrm{H}_{2} \mathrm{SO}_{4}\right)$ yang akan menghasilkan nanokristalin selulosa.

Lignin dan hemiselulosa merupakan struktur amorf terluar yang membungkus selulosa dapat melarut pada larutan alkali, natrium hidroksida. Penggunaan larutan natrium hidroksida pada tahap ini juga bertujuan untuk menekan residual pektin maupun karbohidrat yang terdapat pada serat limbah kubis (Montanari et al, 2005).

Penghilangan lignin dan hemiselulosa dilanjutkan dengan mencampurkan produk dengan larutan natrium hipoklorit $\left(\mathrm{NaClO}_{2}\right)$ untuk memberikan efek bleaching, dampak dari ion klorin yang efektif digunakan sebagai pemurnian permukaan. Rendamen produk hasil bleaching yang telah dikeringkan mencapai $10.06 \%$ dihitung dari bobot serbuk raw kubis yang digunakan.

Produk dari proses bleaching dikategorikan sebagai mikrokristalin selulosa karena memiliki karakteristik organoleptis; putih kekuningan (data pada tabel 1), tidak berbau, serta tidak berasa. Sebagai standar Avicel (PH 103) memiliki ciri organoleptis serbuk putih atau hampir putih. Sebagai upaya optimasi, proses bleaching ditingkatkan menjadi tiga siklus.

Table 1. Hasil identifikasi produk hasil bleaching dan hidrolisis serat selulosa limbah kubis

\begin{tabular}{|c|c|c|c|c|c|}
\hline & Warna & Bau & Uji larutan iodium & Uji pati & Uji kelarutan \\
\hline $\begin{array}{l}\text { Hasil } \\
\text { bleaching }\end{array}$ & $\begin{array}{c}\text { Putih } \\
\text { kekuningan }\end{array}$ & $\begin{array}{c}\text { Tidak } \\
\text { berbau }\end{array}$ & $\begin{array}{l}\text { Positif (berwarna } \\
\text { biru violet) }\end{array}$ & $\begin{array}{c}\text { Positif (tidak } \\
\text { berubah warna ke } \\
\text { biru) }\end{array}$ & $\begin{array}{c}\text { Air (bobot sisa 10,9 mg) } \\
\text { Alkohol (tidak larut) } \\
\text { Asam/ basa (tidak larut) }\end{array}$ \\
\hline $\begin{array}{l}\text { Hasil } \\
\text { hidrolisis }\end{array}$ & $\begin{array}{c}\text { Kuning } \\
\text { kecoklatan }\end{array}$ & $\begin{array}{c}\text { Tidak } \\
\text { berbau }\end{array}$ & $\begin{array}{l}\text { Positif (berwarna } \\
\text { biru violet) }\end{array}$ & $\begin{array}{c}\text { Positif (tidak } \\
\text { berubah warna ke } \\
\text { biru) }\end{array}$ & $\begin{array}{c}\text { Air (bobot sisa } 12.5 \text { mg) } \\
\text { Alkohol (tidak larut) } \\
\text { Asam/ basa (tidak larut) }\end{array}$ \\
\hline
\end{tabular}


Konfirmasi kedua produk selanjutnya dilakukan menggunakan instrumen Fourier Transform Infrared (FT-IR) Spectroscopy dengan tujuan untuk mengidentifikasi struktur selulosa dan evaluasi tidak ditemuinya perubahan struktur selulosa selama proses modifikasi.

Pengujian dilakukan pada sampel raw (bahan mentah) serbuk kubis, hasil bleaching (mikro kristalin selulosa), hasil hidrolisis asam (nanokristalin selulosa) serta Avicel PH 103 sebagai sampel pembanding.

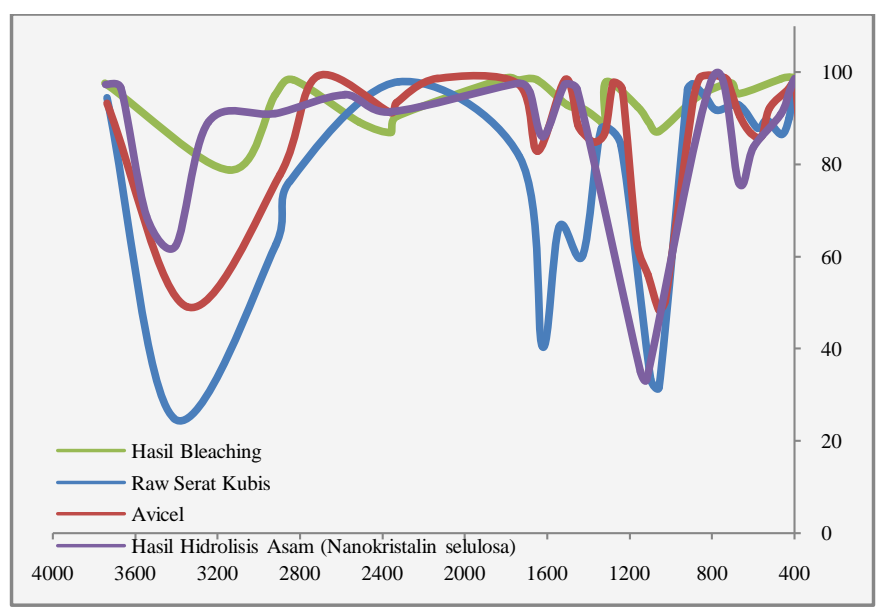

Gambar 1. Perbandingan spektra FT-IR serat selulosa limbah kubis, produk bleaching, Avicel sebagai pembanding, dan produk hidrolisis (nanomristalin selulosa).

Spektra FT-IR seperti pada gambar 1, menunjukkan gugus fungsi spesifik selulosa tetap ditemui pada setiap produk tahapan modifikasi yang dilakukan. Gugus spesifik tersebut mencakup gugus O-H (3414 $\left.\mathrm{cm}^{-1}\right)$; gugus $\mathrm{C}-\mathrm{H}\left(2920 \mathrm{~cm}^{-1}\right)$; gugus $\mathrm{C}=\mathrm{O}\left(1734 \mathrm{~cm}^{-}\right.$ $\left.{ }^{1}\right)$; -OH $\left(1625 \mathrm{~cm}^{-1}\right)$; C-O $\left(1232 \mathrm{~cm}^{-1}\right)$; gugus $-\mathrm{CH}_{2}$ $\left(1430 \mathrm{~cm}^{-1}\right)$. Perubahan intentsitas spektra yang ditampilkan pada gambar 1, merupakan konfirmasi bahwa modifikasi yang dilakukan pada serat selulosa terjadi secara fisika tanpa melibatkan perubahan kimiawi, dengan asumsi perubahan sisi amorf menjadi krsital (Montanari et al, 2005, Lu et al, 2011, Ioelovich, 2012)

Kisi kristal yang terbentuk pada produk serta indeks kristalitasnya ditentukan dengan X-Ray Difrractometer. Pada gambar 2 terlihat perbedaan intensitas dari pola difraksi puncak puncak yang terbentuk. Perubahan intensitas tersebut menunjukkan perubahan kristalinitas dari selulosa yang masih mempunyai permukaan amorf menjadi produk kristalin (25). Indeks kristal dihitung berdasarkan persamaan Segal (24).

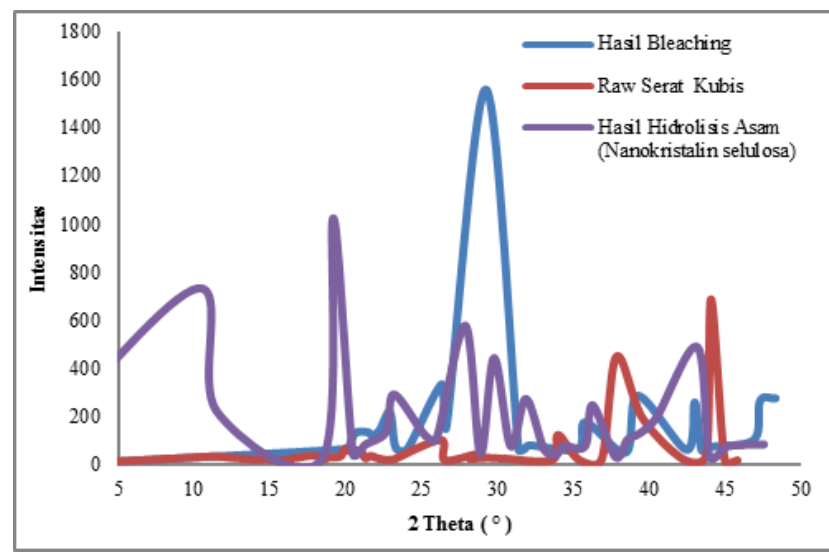

Gambar 2. Perbandingan intensitas difraksi serat selulosa limbah kubis, produk bleaching, dan produk hidrolisis. Data puncak masing-masing difraktogram digunakan pada analisis indeks kristalitas sampel.

Pada table 2, serat selulosa alami kubis sebagai bahan mentah menunjukkan indeks kristal yang rendah hanya 7,41\%. Hal ini sekaligus sebagai indikasi bagian amorf pada serat. Peningkatan indeks kristal mulai teridentifikasi pada produk bleaching mencapai $69,68 \%$ sebagai dampak proses pengilangan lignin dan hemiselulosa. Keberadaan selulosa diindentifikasi pada hasil difraktogram umumnya ditandai dengan keberadaan selulosa tipe I dengan melihat intensitas puncak difraksi pada $2 \theta$ sekitar $22^{\circ}-23^{\circ}$, sedangkan bagian amorf dari selulosa tipe I pada intensitas puncak difraksi terendah sekitar $18^{\circ}$. Selulosa tipe I merupakan selulosa yang banyak dihasilkan pada tumbuhan yang terdiri atas rangkaian kristal dan bagian amorf (Effendi et al, 2015, Zain et al, 2014, Kaplan, 1998, Lu and Hseih, 2011)

Tabel 2. Hasil perhitungan indeks kristal berdasarkan data difraksi XRD.

\begin{tabular}{cccccc}
\hline \multirow{2}{*}{ Sampel } & \multicolumn{2}{c}{$\left.\mathbf{( I 0 0 2 )} \mathbf{(}^{\circ}\right)$} & \multicolumn{2}{c}{$\left.\mathbf{( I a m )} \mathbf{(}^{\circ}\right)$} & $\begin{array}{c}\text { Indeks } \\
\text { Kristal (\%) }\end{array}$ \\
\cline { 2 - 6 } & $\mathbf{2 \theta}$ & Int. & $\mathbf{2 \theta}$ & Int. & $\begin{array}{c}\text { I002-Iam/ } \\
\text { I002*100 }\end{array}$ \\
\hline $\begin{array}{c}\text { Serat } \\
\text { selulosa }\end{array}$ & $22,2^{\circ}$ & 27 & $18,6^{\circ}$ & 25 & 7,41 \\
\hline $\begin{array}{c}\text { Hasil } \\
\text { bleaching }\end{array}$ & $22,9^{\circ}$ & 221 & $19,8^{\circ}$ & 67 & 69,68 \\
\hline $\begin{array}{c}\text { Hasil } \\
\text { Hidrolisis } \\
\text { Asam }\end{array}$ & $23,2^{\circ}$ & 141 & $19,2^{\circ}$ & 31 & 78,01 \\
\hline
\end{tabular}

Indeks kristal hasil hidrolisis asam menunjukkan kristalinitas tertinggi sebesar 78,01\% berdasarkan perhitungan metode Segal, dengan $\mathrm{I}_{002}$ merupakan intensitas maksimum peak pada daerah $2 \theta=22^{\circ}-23^{\circ}$ (bagian kristal) dan $\mathrm{I}_{\mathrm{am}}$ merupakan intensitas minimum 
peak pada daerah $2 \theta=18^{\circ}-19^{\circ}$ (bagian amorf). Penurunan material non-selulosa pada hasil hidrolisis asam menunjukan puncak difraksi $20^{\circ}-22^{\circ}$ dari selulosa menjadi sempit dan tajam (Montanari et al, 2005, Lu et al, 2011, Ioelovich, 2012) dan mengalami peningkatan kristalinitas, seperti pada gambar 2.

Hasil analisis difraktogram XRD juga digunakan usntuk estimasi ukuran kristal dengan menggunakan persamaan Scherrer dan aplikasi Match $^{\circledR}$ (Crystal Impact). Estimasi ukuran partikel berdasarkan metode ini merekomendasikan ukuran kristal selulosa bahan mentah mencapai $1379,07 \mathrm{~nm}$; produk bleaching 719,15 nm; dan hasil hidrolisis asam (nanokristalin selulosa) mengecil menjadi 58,91 $\mathrm{nm}$.

Mempertimbangkan evaluasi pendahuluan kualitas produk yang dilakukan, pengolahan limbah kubis menjadi nanokristalin selulosa bernilai tinggi sangat potensial dilanjutkan, terutama signifikannya pencapaian indeks kristal yang dihasilkan.

\section{KESIMPULAN}

Nanokristalin selulosa dapat diproduksi dari limbah kubis dengan metode hidrolisis asam dengan indeks kristal 78.01\% dan estimasi ukuran kristal rata-rata sebesar $58.91 \mathrm{~nm}$.

\section{UCAPAN TERIMAKASIH}

Terimakasih kepada Laboratorium Kimia Farmasi, Farmakognosi-Fitokimia, dan Biofarmaka UNHAS sebagai sarana penunjang penelitian ini.

\section{DAFTAR PUSTAKA}

Baloch, AB., Xia, X., Sheikh, SA. (2015). Proximate and mineral compositions of dried cauliflower (brassica oleracea l.) grown in sind, Pakistan. Journal of Food and Nutrition Research. 213219.

Bharimalla, AK., Desmukh, SP., Patil, PG., Vigneshwaran, N. (2015). Energy efficient manufacturing of nanocellulose by chemoand bio-mechanical processes: a review. World Journal of Nano Science and Engineering. 5, 204-212.

Effendi, DB., Rosyid, NH., Nandiyanto, ABD., Mudzakir. (2015). A. Review: sintesis nanoselulosa. Jurnal Integrasi Proses. 5, 6174.

Filson, PB., Benjamin, E., Dawson, A., Diane, SB. (2009). Enzymatic-mediated production of cellulose nanocrystals from recyclid puls. Green Chemistry.11.1808:1814.

Ioelovich, M. (2012). Optimal conditions for isolation of nanocrystalline cellulose particle. Nanoscience and Nanotechnology. 2(2), 9-3.

Kaplan, DL. (1998). Biopolimers From Renewable Resources. Springer. USA. Hal.52-53.

Lu, P., Hseih, YL. (2011). Preparation and Characterization of Cellulose Nanocrystals From Rice Straw. Carbohydrate Polimers. 87, 564-573.

Montanari, S., Mohamad, R., Laurent H., Miche, RV. (2005). Topochemistry of carboxylated cellulose cellulose nanocrystals resulting from tempo-mediated oxidation. Macromooleculs. 38. 1665-1671.

Na Ma., Liu D., Liu Y., Su G. (2015). Extraction and characterization of nanocellulose from xanthoceras sorbifolia husk. International Journal of Nanoscale and Nanoengineering.2(6).43-50.

Peng, BL., Dhar, N., Liu, HL., Tam KL. (2011). Chemistry and Application of Nanocrystalline Cellulose and Its Derivates: A Nanotechnology Perspective. The Canadian Journal of Chemical Engineering. 9999.11.

Rosli NA., Ahmad, I., Abdullah, I. (2013). Isolation and characterization of cellulose nanocrystals from Agave angustifolia fibre. Bioresources, 8, 1893-1908.

Rowe, RC., Sheskey, PJ., Quinn, ME. (2009). Handbook of pharmaceutical excipient sixth edition. Pharmaceutical Press. 129-134.

Sumpena, U. Budidaya kubis. Badan Penelitian dan Pengembangan Pertanian Kementrian Pertanian.

The Department of Health. (2001). British Pharmacopoeia. London. The Stationary Office. 8-52

Yue, Y. (2011). A Comparative Study of Cellulose I and II fibers and Nanocrystals. Thesis. Beiolngjiang Institute of Science and Technology

Zain, NFM., Yusop, SM., Ahmad, I. (2014). Preparation and characterization of cellulose and nanocellulose from pomelo (Citrus 
grandis) albedo. Journal Nutrition and Food, $5,1-4$

Zulharmita, Dewi, SN., Mahyuddin. (2012). Pembuatan Mikrokristalin selulosa dari ampas tebu (Saccharum officinarum L.), Jurnal Sains dan Teknologi Farmasi, 17, 158-163. 